\title{
Integrated Remote Sensing and Geophysical Investigations of the Geodynamic Activities at Lake Magadi, Southern Kenyan Rift
}

\author{
Akinola Adesuji Komolafe, ${ }^{1}$ Zacharia Njuguna Kuria, ${ }^{2}$ Tsehaie Woldai, ${ }^{3}$ \\ Marleen Noomen, ${ }^{3}$ and Adeleye Yekini Biodun Anifowose ${ }^{1}$ \\ ${ }^{1}$ Department of Remote Sensing and Geoscience Information System, The Federal University of Technology Akure, PMB 704, \\ Ondo State, Akure 340001, Nigeria \\ ${ }^{2}$ Department of Geology, University of Nairobi, P.O. Box 30197-100, Nairobi, Kenya \\ ${ }^{3}$ International Institute for Geoinformation Science and Earth Observation (ITC), University of Twente, \\ 7500 AE Enschede, The Netherlands
}

Correspondence should be addressed to Akinola Adesuji Komolafe, komolafe22010@alumni.itc.nl

Received 4 July 2012; Revised 8 October 2012; Accepted 23 October 2012

Academic Editor: Salvatore Gambino

Copyright (C) 2012 Akinola Adesuji Komolafe et al. This is an open access article distributed under the Creative Commons Attribution License, which permits unrestricted use, distribution, and reproduction in any medium, provided the original work is properly cited.

\begin{abstract}
The tectonic lineaments and thermal structure of Lake Magadi, southern Kenyan rift system, were investigated using ASTER data and geophysical methods. Five N-S faults close to known hot springs were identified for geoelectric ground investigation. Aeromagnetic data were employed to further probe faults at greater depths and determine the Curie-point depth. Results indicate a funnel-shaped fluid-filled (mostly saline hydrothermal) zone with relatively low resistivity values of less than $1 \Omega$-m, separated by resistive structures to the west and east, to a depth of $75 \mathrm{~m}$ along the resistivity profiles. There was evidence of saline hydrothermal fluid flow toward the surface through the fault splays. The observed faults extend from the surface to a depth of $7.5 \mathrm{~km}$ and are probably the ones that bound the graben laterally. They serve as major conduits for the upward heat flux in the study area. The aeromagnetics spectral analysis also revealed heat source emplacement at a depth of about $12 \mathrm{~km}$. The relative shallowness implies a high geothermal gradient evidenced in the surface manifestations of hot springs along the lake margins. Correlation of the heat source with the hypocenters showed that the seismogenetic zone exists directly above the magmatic intrusion, forming the commencement of geodynamic activities.
\end{abstract}

\section{Introduction}

Uprising of magma during rifting process often results in various geodynamic activities such as the surface expressions of tectonic lineaments, earthquakes, and manifestations of geothermal resources. These lineaments, such as faults and fractures, play major roles in the study of the evolution and dynamism of the rift zones. Investigations into the tectonic lineaments and subsurface thermal structure are crucial to the understanding of geothermal activities and processes associated with active regions. According to Blewitt et al. [1], continuous accumulation of tectonic strain helps to maintain faults and fractures as conduits for fluid flow thereby sustaining the geothermal systems. Hydrothermal fluid transportation in the form of hot springs in these active regions is largely dependent on the existence of lineaments (faults and fractures) and deep-seated thermal processes [2-4].

Geothermal energy is defined as the heat generated within the earth, which could be exploited for use. Mary and Mario [5] associate geothermal resources with tectonically active regions, generated as a result of temperature differences within the asthenosphere where convective movements are formed. The fluids, which are generated from the deep geothermal source sometimes, manifest on the surface in the form of hot springs and fumaroles through different conduits (fractures) in the subsurface. Evidently, critically stressed fractures have been discovered to play an important role in most geothermal fields $[1,6]$. Lake Magadi, located in the southern Kenya rift, is a typical example of an environment with high geodynamic activity expressed by geothermal 
activities [7-9]. Unlike some other geothermal regions where the reservoirs containing hot fluids have to be penetrated during exploitation, geothermal resources around Lake Magadi are clearly manifested on the surface in the form of hot springs and trona deposit along the Lake Margin and in the lake, respectively. These surface manifestations of the hot springs have been attributed to the continuous tectonic activities and the presence of various faulting systems in the area $[10,11]$.

In the Kenya rift, geothermal manifestations at many locations have been identified [12], the most active and currently producing being the Olkaria geothermal field in the north of the Lake Magadi area. The latter exists within an old caldera complex cut by N-S normal faults in the surface. The surface manifestations are in the form of hot springs. The warm ground which is common in the area is associated with N-S normal faulting as reported also for Magadi area [12]. Lake Magadi water is mostly derived from underground hot water inflow with a continuous recharge from the surface waters $[10,13]$. It is therefore important to investigate Lake Magadi's thermal structure by delineating the depth to the heat source and the geometry of the subsurface fractures in order to know the distribution and the flow paths of hydrothermal fluids as a prelude to understanding the geothermal potentials of the field.

Previous investigations indicated active deformation both south and north of Lake Magadi [14-16]. The neotectonics and extension direction studies around the lake were designed to characterize the surface tectonic lineaments and crustal structure using remote sensing [14], borehole, and geophysical data [17]. However, the subsurface components, especially fluids (mostly hydrothermal) infilling fractures in the area, have not been investigated. In the Lake Magadi area, the presence of fluid-filled, high microcrack porosity (fractures) in the upper crust was proposed by Ibs-von Seht et al. [7] using seismic methods. This was inferred from a low velocity anomaly experienced in the central part of the area and from the presence of hot springs. The role of $\mathrm{N}$ $S$ faults in the south of Lake Magadi as major conduits for geothermal resources and the deposition of trona in the lake has also been proposed by Jones et al. [10] using geochemical methods. However, the actual subsurface investigation of the influence of N-S faults structures on the hydrothermal fluids in the area has not been done. This study therefore employs the use of integrated remote sensing and geophysical methods, geared towards delineating the heat source as well as understanding the influence of active tectonic lineaments on the hydrothermal fluids around Lake Magadi, and with a view to unveiling the geothermal potentials of the area and the cause of tectonic activities.

\section{The Study Area}

Lake Magadi is situated in the southernmost part of Kenya rift, $120 \mathrm{~km}$ southwest of Nairobi and $20 \mathrm{~km}$ north of the Tanzanian border. It is located within latitudes $1^{\circ} 40^{\prime} \mathrm{S}$, and $2^{\circ} 10^{\prime} \mathrm{S}$, and longitudes $36^{\circ} 00^{\prime} \mathrm{E}$ and $36^{\circ} 30^{\prime} \mathrm{E}$, characterized by a flat plain known as the rift floor [14] (Figure 1). The approximately $100 \mathrm{~km}^{2}$ lake is recharged by saline hot springs (between $26^{\circ} \mathrm{C}$ and $86^{\circ} \mathrm{C}$ ) along the lake margins [10]; most of them lie along the northwestern and southern shorelines of the lake. The lake is made up of trona deposit $\left(\mathrm{Na}_{2} \mathrm{CO}_{3} \cdot \mathrm{NaHCO}_{3} \cdot 2 \mathrm{H}_{2} \mathrm{O}\right)$ up to $40 \mathrm{~m}$ thick and covers an area of $75 \mathrm{~km}^{2}$ resulting from the concentration of different water sources, especially hydrothermal fluid [10]. A chemical analysis of waters collected from the lake showed that Magadi trona is derived from the evaporated concentration and mixing of waters from three sources, namely, dilute surface inflow, relatively deep hot and concentrated groundwater reservoir, and cold concentrated surface brine [18]. For the purpose of this research, sites which are close to the hot springs located in the southern part of the lake were selected (Figure 1).

\section{Geology and Tectonic Settings of Kenya Rift}

The Kenya rift, also called the Gregory rift, is the eastern branch of the continental East African rift system (EARS) which extends to about $3000 \mathrm{~km}$ from Afar triangle to southern Mozambique [14, 19] (Figure 2). Geologically, the rift is made up of Cenozoic volcanic and sedimentary rocks. Baker et al. [20] divided the Cenozoic rocks into four lithostratigraphic units, namely, Miocene basalts, Miocene phonolites, and Pliocene and Quaternary volcanic and sedimentary rocks. The crustal structures of the Kenya rift have been investigated using integrated seismic, magnetic, and gravity data [21-24]. A $5 \mathrm{~km}$ deep, sediment- and volcanic-filled basin on a thinning crust of about $8 \mathrm{~km}$ in a $100 \mathrm{~km}$-wide zone beneath the rift valley was described by Braile et al. [21] using a 2D seismic velocity model.

Baker reported three major stages of rifting, accompanying intense alkaline volcanism in its tectonic development: (1) the prerift stage (30-12 Ma), forming deformation and minor faulting, (2) the half-graben stage (12-4 Ma), forming the main boundary faults, and (3) the graben stage $(<4 \mathrm{Ma})$ with an increase and inward migration of faulting [25]. The volcanism and rifting of the Kenya rift began 40-45 Ma and $\sim 25 \mathrm{Ma}$ ago, respectively, in the north and propagated to the south. Investigations during Kenya Rift International Seismic Project (KRISP) revealed an increase in the crustal extension to the north and the presence of primary low velocity anomalies, which are possibly caused by magma rising from below and are trapped in the uppermost mantle $[23,26]$. Keller et al. [27] revealed that the rift is associated with sharply defined lithospheric thinning and low upper mantle velocities down to depths of over $150 \mathrm{~km}$. Mechie et al. [23, 28], after a detailed study of the structures of the rift from south to north, showed crustal variations along the rift axis from $35 \mathrm{~km}$ in the south beneath the Kenya dome around Lake Naivasha to $20 \mathrm{~km}$ in the north beneath the Turkana region. This variation in crustal thickness along the rift axis has been attributed to a tertiary rifting episode. According to Atmaoui and Hollnack [14], with time, there is a northsouth rift propagation and a shift in volcanism and tectonic activities from the rift margins towards the axial part of the rift floor, accompanied by high fault density. From this, it is expected that the tectonic activity is mainly concentrated in the axial part of the southern 


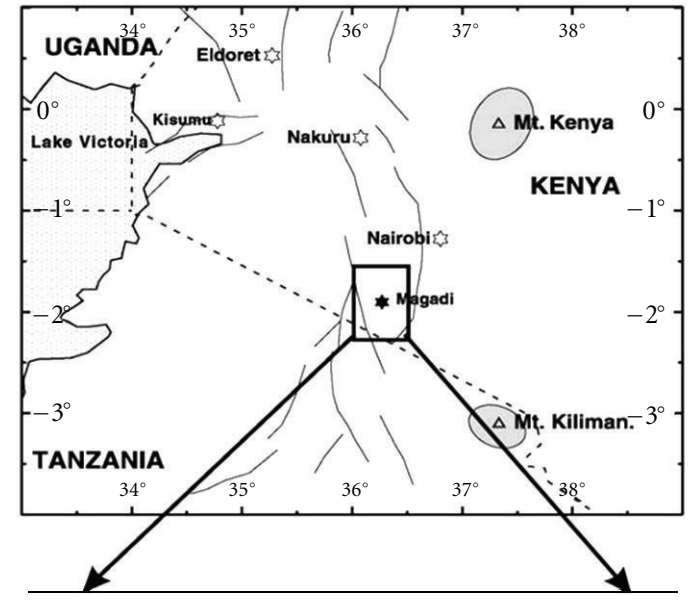

(a)

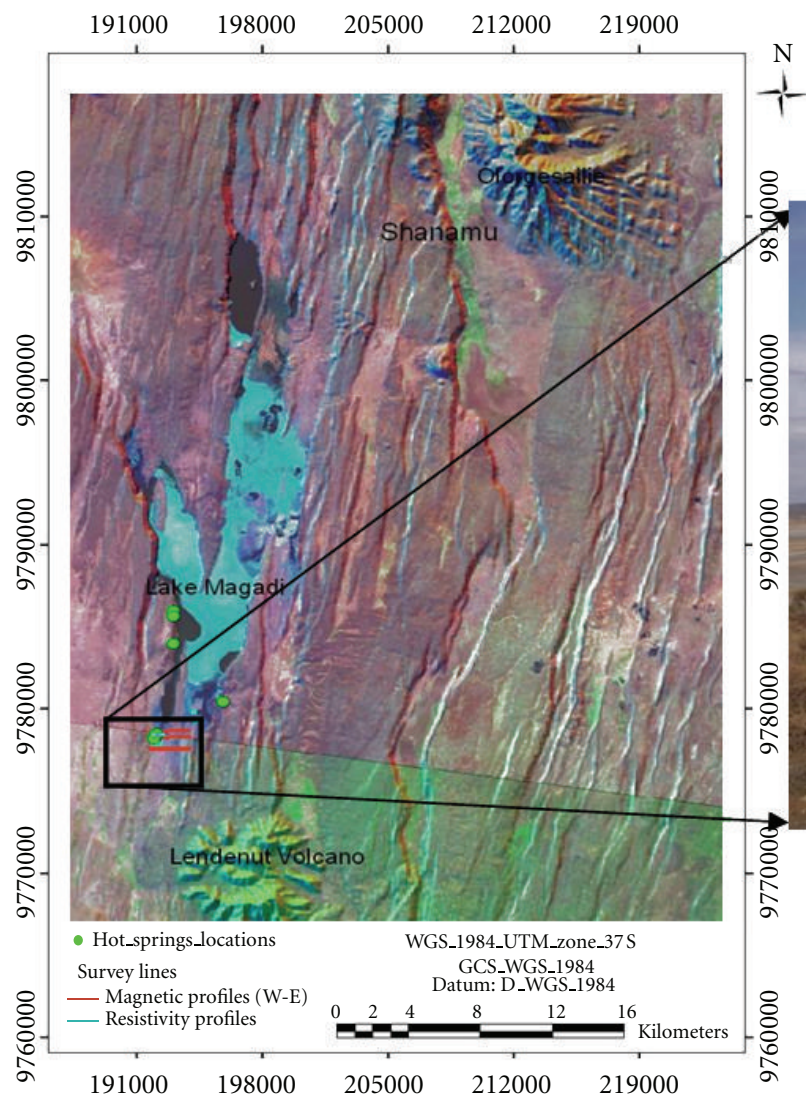

(b)

(c)

FIGURE 1: (a) Geographic location of Magadi area after [14], (b) RGB colour composite of ASTER bands 7-3-1 draped over SRTM DEM, showing the study and survey areas, and (c) field photo showing part of the study area and associated springs.

Kenya rift (Lake Magadi area). They also investigated the tectonic extension direction of southern Kenya rift (Lake Magadi) using structural analysis of open fractures and size characteristics of faults and indicated an E-W to ESEWNW normal faulting extension direction as against the NE-SW extensional stress proposed by Bosworth et al. [15]. Neotectonics studies of the rift revealsfour sets of faults: normal N-S fault, dextral NW-SE fault, strike slip ENE-WSW fault, and sinistral NE-SW fault [29].
In terms of seismicity, Kenya rift shows a relatively low seismic activity compared to the whole of the east African rift systems. Apart from a magnitude of 6.8 recorded in 1928 in the central part of the rift, no events of magnitude more than 5 have been reported [16]. However, a constant rate of approximately $10(M<3)$ events per day for the southernmost part of the rift have been reported by Ibs-von Seht et al. [7]. The strongest event from the southernmost Kenya rift had a magnitude of 4.2, accompanied with 


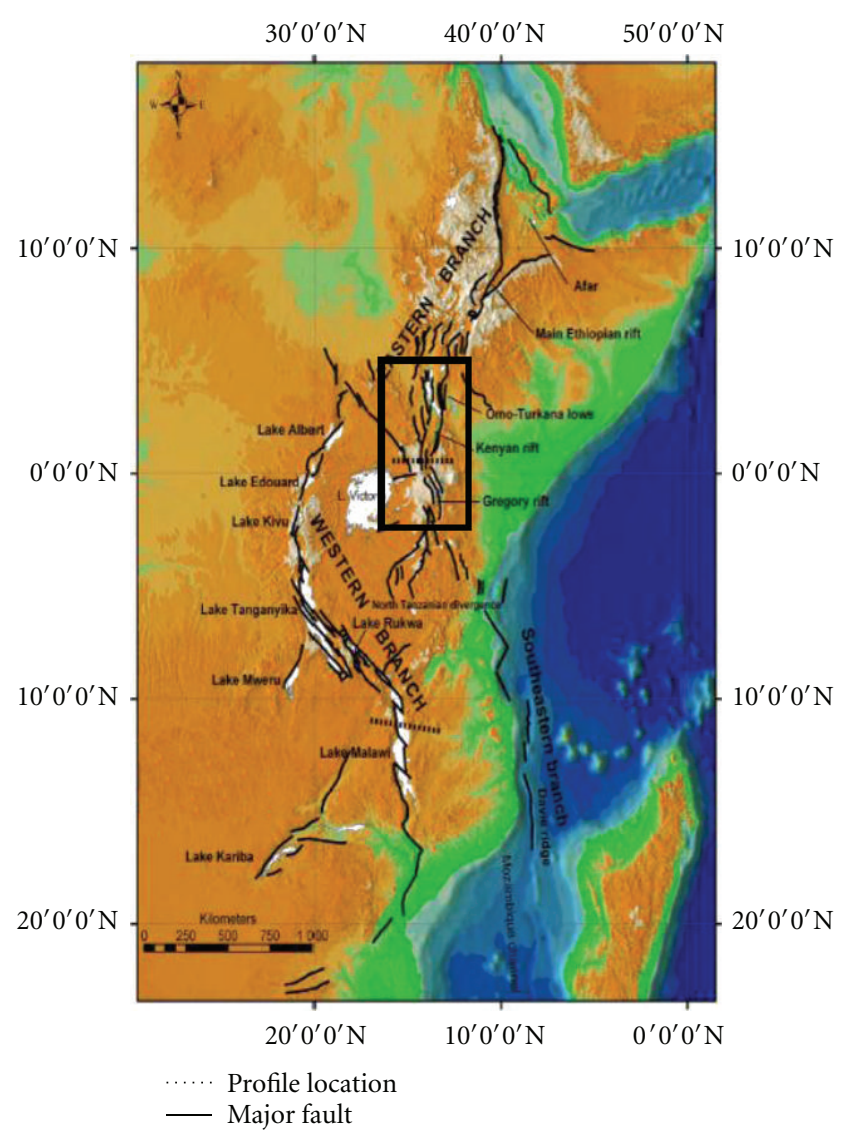

FIGURE 2: East African rift system showing the location of Kenya rift after [19].

a surface crack of several kilometers length in the epicenter region $[7,14]$. This makes the Lake Magadi area the most seismically active region within the Kenya rift.

\section{Geology of Lake Magadi}

The Lake Magadi area is made up of mostly Archean to early Paleozoic crystalline basement rocks and rift-related volcanics and sediments [30]. These can be grouped into three categories as explained by Atmaoui and Hollnack [14], viz: (i) Precambrian metamorphic rocks, (ii) Pliocene to Pleistocene volcanic rocks, and (iii) Holocene to recent lake and fluvial sediments (Figure 3 ). The oldest rocks in the area are the quartzites, gneisses and schists of the basement formation, which is of Archean age. The extrusion of alkali trachytes within the lake as explained by Baker [31] and Baker et al. [20] occurred in the Pleistocene age. In the southern and northern ends of the Lake Magadi area, there is a deposition of irregular interbedded chert rocks which consists of silicified bedded clays on top of alkali trachytes [14]. This was later unconformably deposited on by a thin layer of lake beds known as the Oloronga beds, followed by a series of subparallel faulting system that resulted in the formation of the Lake Magadi rift floor. The formation of the Quaternary sediments occurred within a fault-bounded basin. An integrated seismic, drill hole data and gravity model by Simiyu and Keller [17] revealed sediments and volcanic rocks at the rift floor adjacent to Nguruman escarpment. The model explained the crustal structure of Lake Magadi as having basement rocks at the bottom which are exposed at the western (Tanzanian craton) and eastern (Mozambique belt) flanks and are overlain by Pliocene to Miocene volcanic and sediments rocks. The rift has been discovered to exist in the boundary between the Archan Tanzanian craton and neoproterozoic Mozambique belt, which is characterized by a complex fault zone [30].

\section{Remote Sensing Data Processing and Analysis}

For the structural mapping of the study area, an advanced space-borne thermal emission and reflection radiometer (ASTER) image and a digital elevation model were used were integrated. ASTER is a multispectral imaging system that consists of 14 bands within the electromagnetic spectrum with 3 bands in the visible and near infrared (VNIR) having $15 \mathrm{~m}$ spatial resolution, 6 bands in short wave infrared (SWIR) with $30 \mathrm{~m}$ spatial resolution, and 5 bands in the thermal infrared (TIR) with $90 \mathrm{~m}$ spatial resolution. Because of its better and enhanced spatial resolution especially in the visible and near infrared, ASTER band ratios and colour composites are useful in geologic and structural mapping. The various image scenes were coregistered to the same reference system (WGS 84 zone 37S), layer-stacked, and resampled to the $15 \mathrm{~m}$ spatial resolution of the VNIR. The layer-stacked image was subset to cover the study area. Image colour composites on band 7-3-1 were applied for lineament delineation as demonstrated by Thurmond et al. [32] and Yang et al. [33].

Digital elevation models (DEMs) reveal the surface expressions of the earth's geomorphology and are useful in delineating structural information on the earth's surface [34]. ASTER DEM was used in conjunction with the ASTER image to identify the major fractures of interest, close to the known hot springs in the area for geophysical measurements. After removing the bad pixel values (very low negative values) from the datasets using ENVI software, the study area was subset. The subset DEM was further enhanced using shaded relief with $45^{\circ}$ sun elevation angle of $225^{\circ}$ and $315^{\circ}$ solar azimuths (Figure 4).

The DEM hill-shaded relief was draped on ASTER image RGB combination 7-3-1 for fault identification [33] (Figure 4(a)). The outcome of the interpreted structures from the remote sensing data, together with the existing lineament map, was used to generate a spatial distribution of faults in the area (Figure 4(b)). Five fault systems referred to as A, B, C, D, and E (from the west to the east) in the south of the lake, were targeted for ground investigation (Figure 5). These faults are located close to the known hot springs and are assumed to be the major fluid conduits in the area.

\section{Electrical Resistivity Tomography}

6.1. Resistivity Data Acquisition and Processing. The main objective of deploying resistivity method was to image the geometry of the subsurface fluid conduits (faults and 


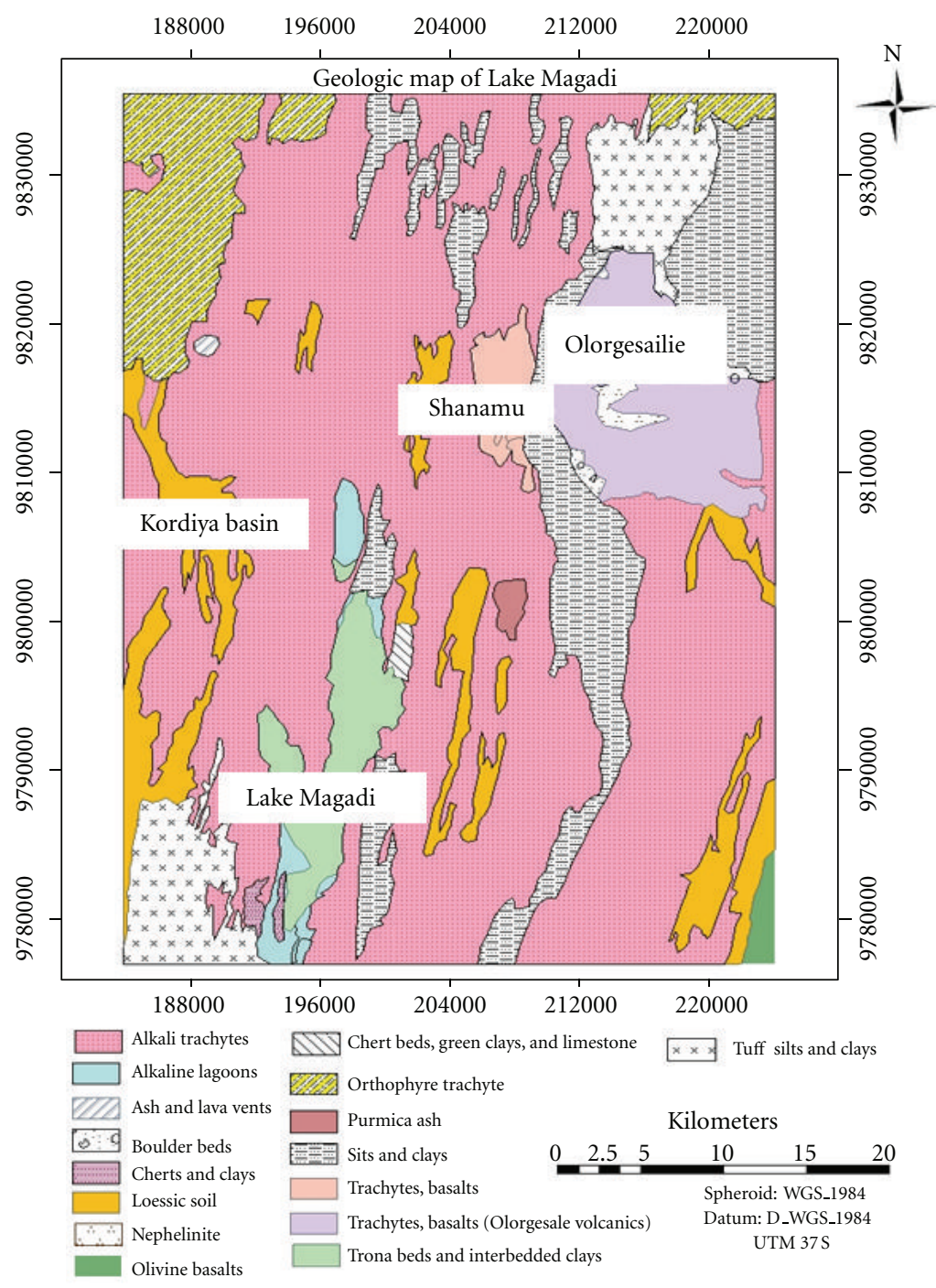

FIGURE 3: Geological map of Lake Magadi area after [31].

fractures) with their fluid content. Resistivity equipment used in this study is the Syscal R1 Plus Resistivity Meter, designed for medium-depth investigation. The Wenner array electrode configuration was adopted for both lateral and vertical resolution.

The first profile (R1) was executed within the sedimentary basin in the southeast of Lake Magadi, between faults D and $\mathrm{E}$ (striking $\mathrm{N} 05^{\circ} \mathrm{S}$ and $\mathrm{N} 20^{\circ} \mathrm{S}$, resp.), while the second profile (R2) exists between the faults C and D (Figure 5). The length of the single profile achieved during the survey was 360 meters using 4 cables (18 electrodes each) with 5-meter separation. In order to increase the lateral extent of the profile, roll-along was performed for R1 covering a distance of $450 \mathrm{~m}$ with the depth of investigation of 75 meters, while the normal single profile (360 m distance) was achieved for R2. The two profiles (R3 and R4) were collected in 2008 (Figure 5) using the same resistivity equipment. These profiles had a lateral distance of $450 \mathrm{~m}$ in the eastwest direction and are separated by $1 \mathrm{~km}$.
The apparent resistivity data for the four profiles were inverted in the Earth Imager software (Advanced Geosciences Inc.).

6.2. Georesistivity Structures along Resistivity Profiles. The descriptions of each resistivity profiles, their resistivity distributions, and interpretation are explained in the following.

6.2.1. Profile One (R1). Total lateral extent of $450 \mathrm{~m}$ with $5 \mathrm{~m}$ electrode spacing apparent resistivity was inverted to a penetrating depth of $75 \mathrm{~m}$. The $2 \mathrm{D}$ resistivity model is characterized by relatively low resistivity distributions with the highest resistivity value of $2.0 \mathrm{ohm}-\mathrm{m}$ (Figure 6 ). The highly fluid saturated saline alkaline trachytes with mud and clay, which are predominantly seen on the surface, show a very low resistivity zone $(0.10-0.33 \mathrm{ohm}-\mathrm{m})$ with thickness of approximately $10 \mathrm{~m}$. The zone commences at $45 \mathrm{~m}$ station along the profile (west-east) with a lateral extent of about $305 \mathrm{~m}$ towards the fault E. Below that is a low resistivity 


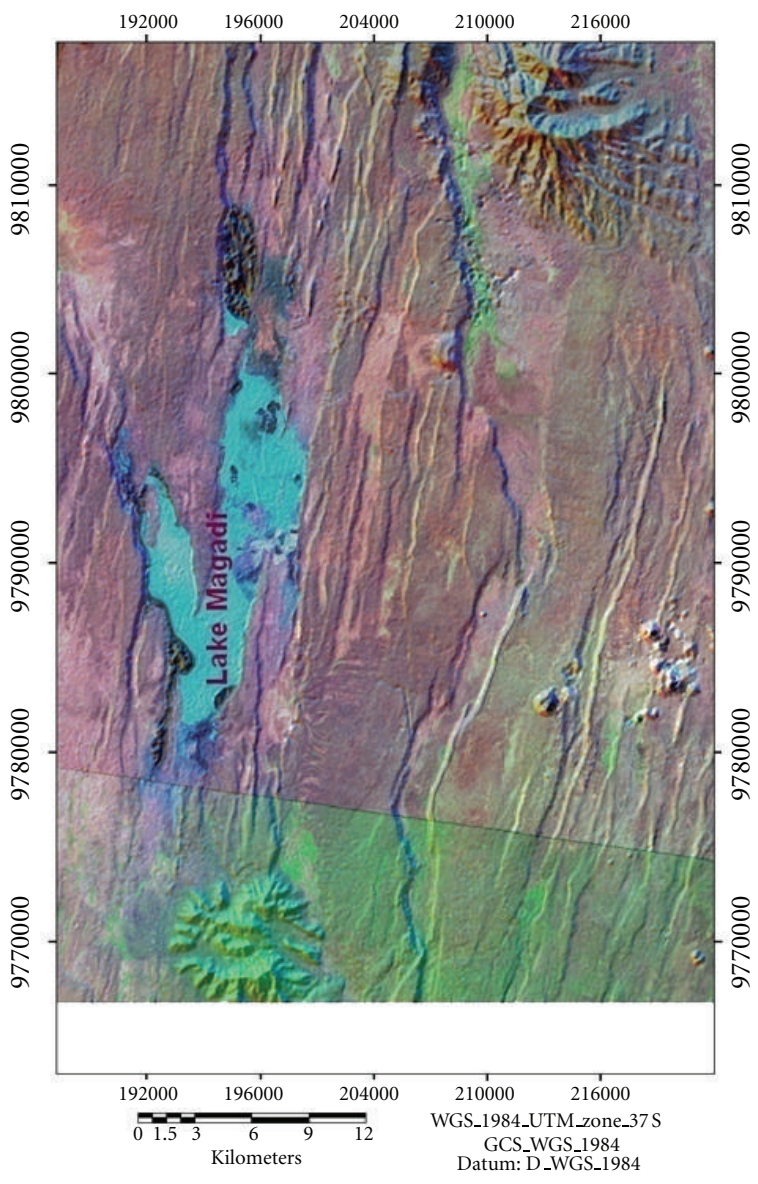

(a)

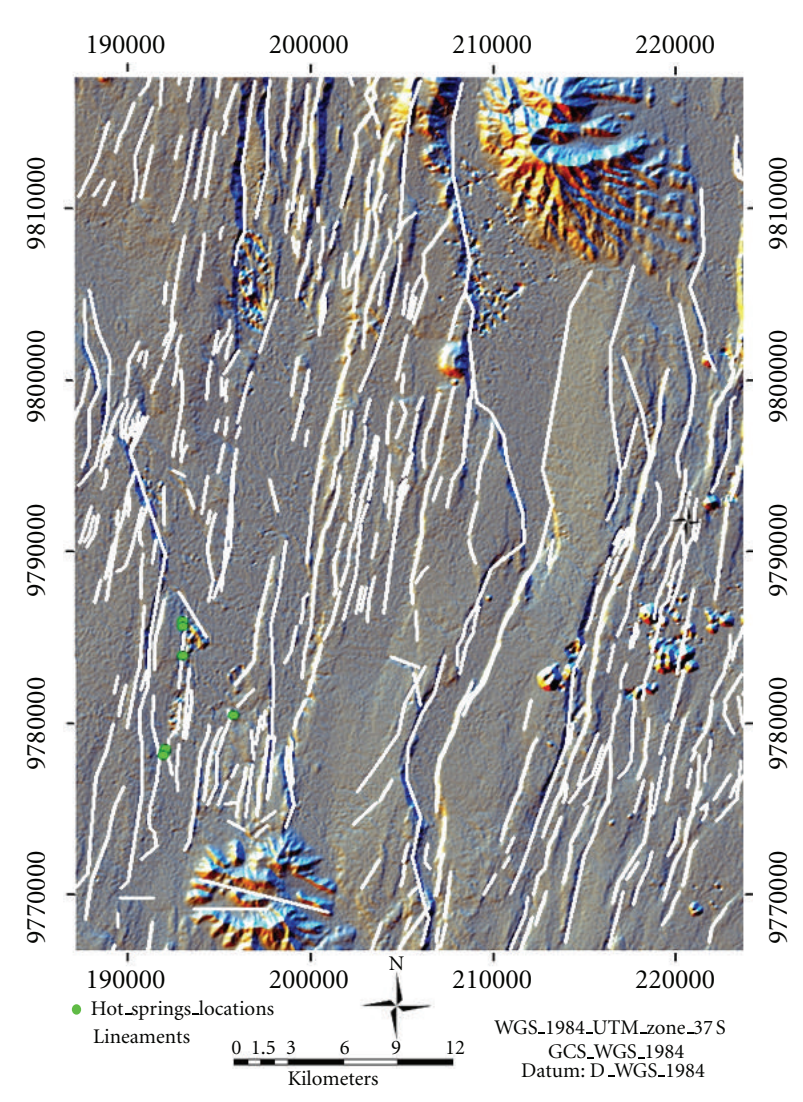

(b)

FIGURE 4: (a) Shaded relief ASTER DEM Image (30 m resolution) draped over by ASTER bands 7-3-1. The images show the structural trend of Lake Magadi. (b) Extracted lineaments from remote sensing data overlaid on Aster DEM.

$(0.15-0.33 \mathrm{ohm}-\mathrm{m})$ attributed to saline fluids, probably hydrothermal. These are clearly manifested on the surface very close to fault $\mathrm{E}$ in the study area. The saline nature of Magadi springs and brine is reported to be due to the concentration of both surface (meteoric) waters and saline groundwater (or hot water) [10, 18], Eugster [35]. There is an increase in the resistivity profile from near surface to the bottom of the profile. This could be attributed to the salinity differences beneath Lake Magadi. The salinity and the presence of clay must have resulted in the very low resistivity values in the area. Weathered chert within the fault zone D shows a relatively high resistivity $(0.65-2.0 \mathrm{ohm}-\mathrm{m})$ with a possible fault splay which extends to depth of about $65 \mathrm{~m}$.

6.2.2. Profile Two (R2). In Figure 7, the alkaline trachytes, clay and mud show low resistivity similar to that in profile $\mathrm{R} 1$. Continuous vertical variations in the bulk resistivities as revealed in the model could be attributed to salinity differences as indicated also in profile $\mathrm{R} 1[10,36]$. The relatively high resistivity $(2.1-5.8 \mathrm{ohm}-\mathrm{m})$ at fault $\mathrm{D}$ coincides with the chert rock linear alignment (N-S) in the study area. The chert separates the saline fluid-filled sediments both to the west and east of the fault $\mathrm{D}$ and it is assumed to have been deposited within the fault zone [14]. The resistive structure $(1.0-5.8 \mathrm{ohm}-\mathrm{m})$, which is covered by the sediments shows some degree of fracturing in the subsurface. The alkaline trachytes and clay show approximately the same thickness as in profile R1. The profile also shows a decrease in the saline concentration as the resistivities gradually increase. Generally, the two models show similar geo-electric structure in terms of alkaline sediment thickness, saline fluids and fractures.

6.2.3. Profile Three (R3). Inverted 2D resistivity model of profile R3 shows approximately funnel-shaped feature with low resistivity (Figure 8). This funnel-shaped feature, which extends to the surface, is bounded on both sides by high resistivity structures; it coincides with the hot springs' locations, which exist between faults A and B (Figure 5). The low resistivity is characteristic of a typical geothermal environment where saline hot fluid circulates within the reservoir and finds its way to the surface through a connecting path $[37,38]$. The geoelectric structure shows the subsurface faults which can be classified as normal fault with splays both to the west and to east. The upward inclination of the fluids both to the west and to east within the resistive 


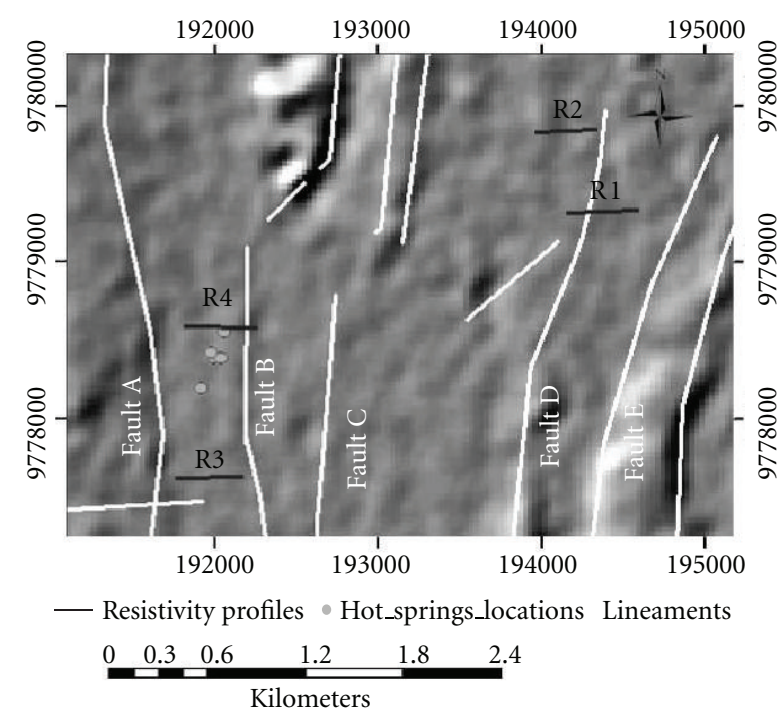

FIgURE 5: Hill-shaded ASTER DEM showing the locations of resistivity profiles (R1, R2, R3, and R4) in the study area.

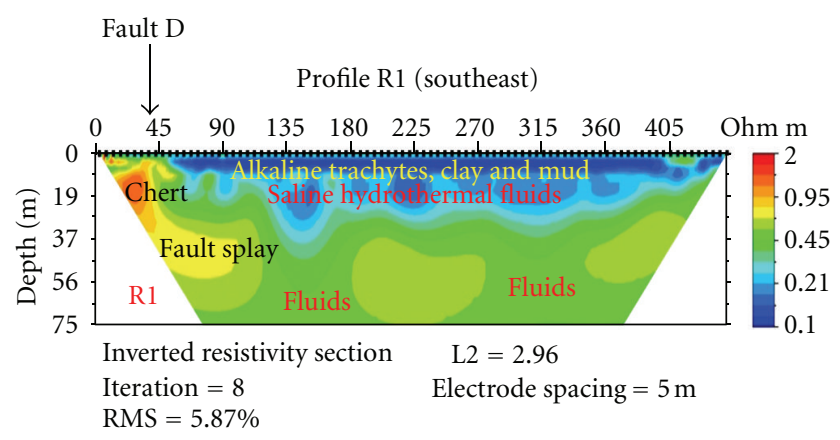

FIGURE 6: Inverted 2D resistivity section for profile 1 across fault D and towards fault $\mathrm{E}$ in the southeast of Lake Magadi.

body shows probably that the fluid path follows the direction of the conduits (faults) to the surface.

6.2.4. Profile Four (R4). The depth of investigation of the inverted resistivity is $75 \mathrm{~m}$ with well-defined geological units comprising faults splay both to west and east (Figure 9). The geoelectric structures show similar unit with the profiles (1 and 3) in terms of fault inclination and funnel-shaped structure. The low resistivity observed is probably due to the presence of the hot springs which in principle increases its conductivity. The hot fluid $(0.18-1.0 \mathrm{ohm}-\mathrm{m})$ upward movement with funnel-shaped structure follows the path between fault zones (about $125 \mathrm{~m}$ wide). The fault zone exists between the high resistivity rock bodies. In general, the saline hydrothermal fluid shows a sharp resistivity contrast with the surrounding rocks. From field observations, the high resistivity in the near surface can be attributed to the volcanic rock outcropping within the hot springs.

\section{Aeromagnetic Data}

7.1. Aeromagnetic Data Analysis. The aeromagnetic data used in this study is part of the African Magnetic Mapping

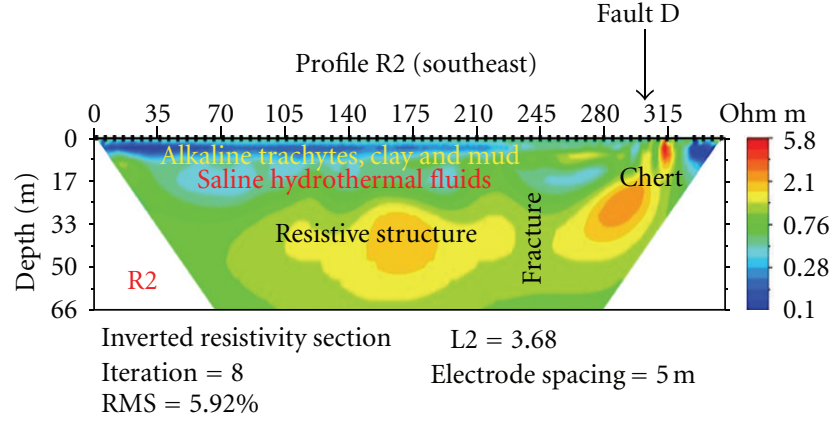

Figure 7: Inverted 2D resistivity section for profile 2 . The profile crosses fault $\mathrm{D}$ almost perpendicular to its strike direction.

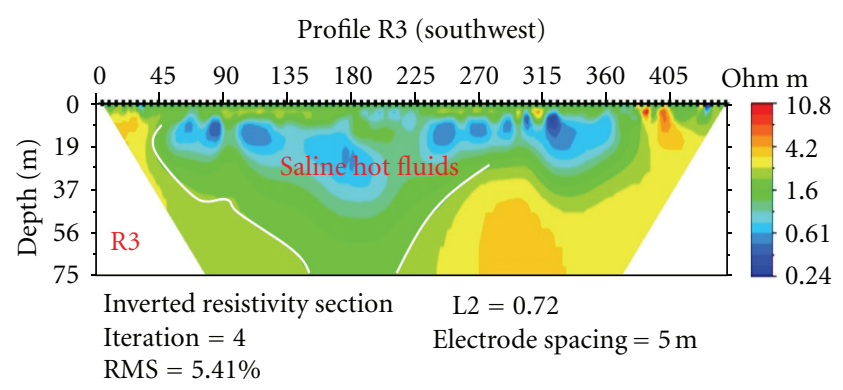

FIGURE 8: Inverted 2D resistivity section for profile 3 between fault $A$ and fault $B$ in the southwest of Lake Magadi.

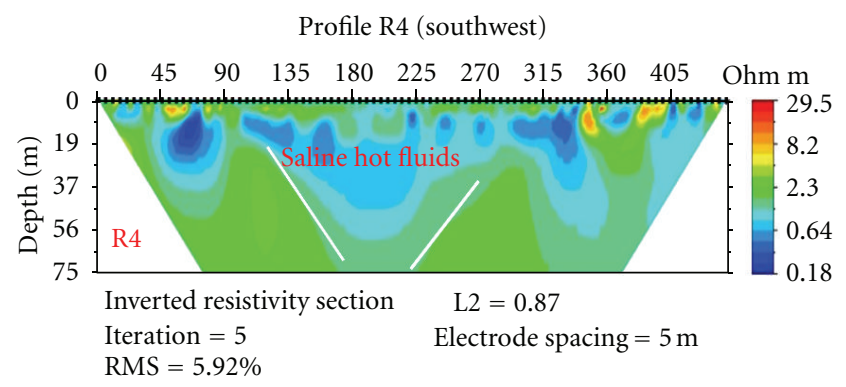

FIGURE 9: Inverted 2D resistivity section for profile 4 across fault $B$ towards fault A in the southwest of Lake Magadi.

Project (AMMP), which was intended to compile airborne magnetic data for some parts of Africa. The aeromagnetic data in the study area was acquired in 1987 by Compagnie Generale de Geophysique (CGG) with $2 \mathrm{~km}$ line spacing, flight direction of $90^{\circ}$ (W-E), and flying height of $2896 \mathrm{~m}$ above sea level. Magnetic data on flight lines 320 and 322, covering about $7.7 \mathrm{~km}$ long close to the resistivity profiles were, extracted from the total magnetic intensity map of the aeromagnetic data as shown in Figure 10. The data processing (levelling correction and geomagnetic field removal) was done by AMMP. The magnetic grid was created using $1 \mathrm{~km}$ cell size with AMMP grid projection system, reprojected to WGS 84, UTM $37 \mathrm{~S}$ projection later to conform to the projection used in this study. The extracted aeromagnetic data were processed and inverted using 2D Euler deconvolution software developed by Cooper [39]. Magnetic intensity 


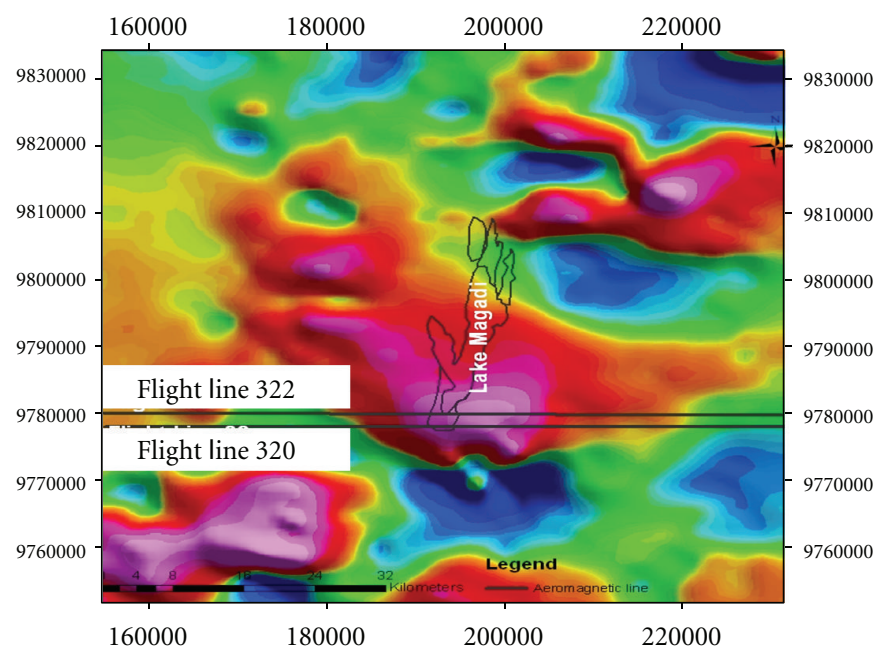

FIGURE 10: Colour-shaded aeromagnetic total magnetic intensity (TMI) grid data for Lake Magadi area.

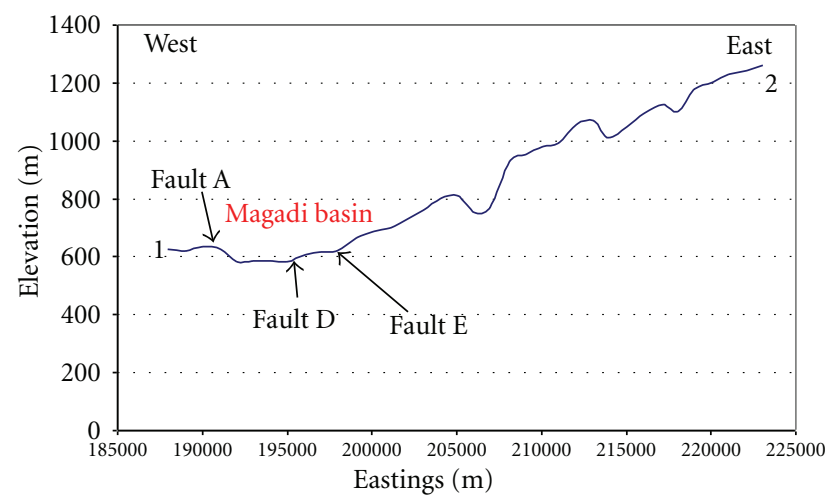

(a)

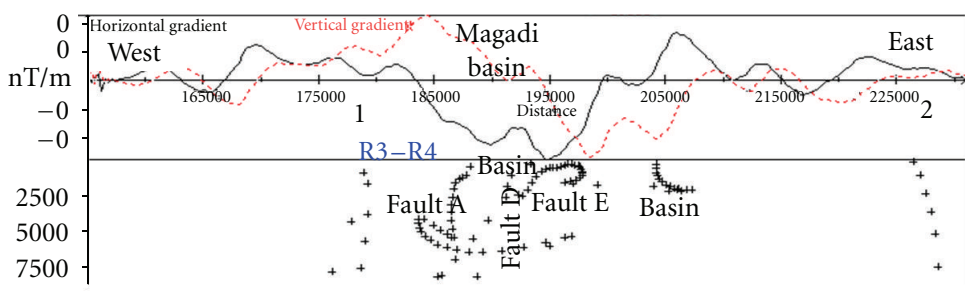

(b)

FIGURE 11: (a) Extracted topography elevations of Lake Magadi area from Aster DEM along flight line 330 showing surface faults and grabens. (b) 2D Euler deconvolution solutions from aeromagnetic data along flight line 320. The plus signs are structural index of 1 .

of 33414 , inclination of $-26.3^{\circ}$, and declination of $0.002^{\circ}$ with structural index of 1 (steep contacts) derived from the International Geomagnetic Reference Frame (IGRF) 2005 model were used as inputs to the Euler software to construct the subsurface magnetic sources along the selected profile lines.

7.2. $2 D$ Interpretation of the Aeromagnetic Profiles. The processed aeromagnetic data for lines 320 and 322 are shown in Figures 11 and 12. The flight lines, which are $2 \mathrm{~km}$, separated from each other show similar subsurface geometry, both in frequency and amplitudes. Most of the Euler solutions are concentrated along the rift axis while the basin is marked by the absence of magnetic sources. These observations are in line with the results experienced in the northern part of the Kenya rift by Mariita and Keller [40]. The magnetic sources from 2D Euler correspond approximately to the top of the magnetic sources. These sources reflect rock beneath the thick sediment within the axial part of the rift basin. The subvertical alignment and scattering of the Euler solutions reveal the existence of tectonic activities [8, 41, 42] which extend to a depth of $7.5 \mathrm{~km}$ (Figures 11 and 12). The magnetic sources correspond largely to the tectonic structures (faults). These tectonic structures, approximately 


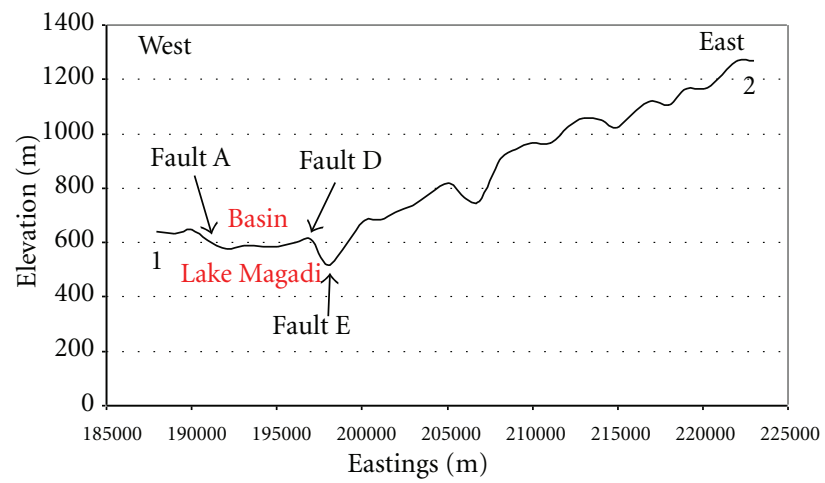

(a)

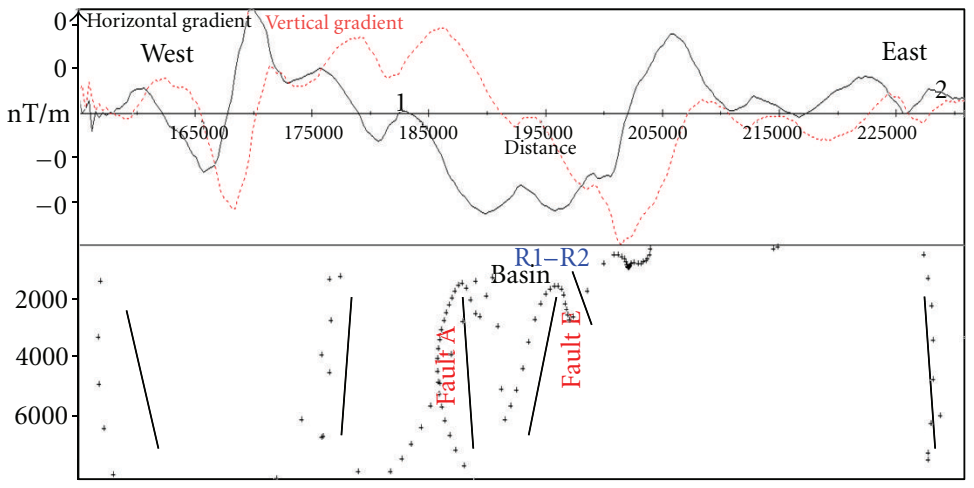

(b)

FIGURE 12: (a) Extracted topography elevations of Lake Magadi area from Aster DEM along flight line 322 showing surface faults and grabens. (b) $2 \mathrm{D}$ Euler deconvolution solutions from aeromagnetic data along flight line 322 . The plus signs are structural index of 1.

at a depth of $7.5 \mathrm{~km}$, correspond to the established surface N-S trending faults A, D, and E in the south of Lake Magadi, which bounds the graben in the surface as seen in the topographic profiles (Figures 11(a) and 12(a)).

The lack of magnetic signal between the faults in the subsurface could be because of the presence of hydrothermal fluids within the basin, which are delineated from ERT profiles. This zone exists between faults A, D, and E, which coincides with the ERT profiles (R1-R4). Faults B and C are mostly shallow; they are not clearly manifested in the aeromagnetic profiles.

\section{Spectral Analysis and Curie-Point Depth Estimation}

Curie-point is defined as the temperature (above $580^{\circ} \mathrm{C}$ ) at which magnetic material loses its magnetic properties or susceptibility as a result of the high temperature [43]. This point is assumed to be at the depth of the geothermal source (magmatic chamber) where most geothermal reservoirs tap their heat from in a geothermal environment. Curiepoint temperature depths provide general information on both regional and local temperature distribution as well as geothermal gradients. According to Gürer and Bayrak [44], Curie-point depth is one of the methods of examining thermal structural data of the crust using aeromagnetic data.
Aeromagnetic data have been used widely to determine the depth to the Curie isothermal point using spectral analysis $[43,45,46]$. In general, for all magnetic surveys above or at the surface, a near-surface magnetic anomaly is characterized by its short wavelength, while a demagnetized body (heated above the Curie-point) shows a long wavelength and low amplitude magnetic anomaly. The difference between the short and the long wavelengths can be used to determine the Curie-point depth which is assumed to be the depth to deep heat source [43].

The spectral analysis method provides relationship between the spectrum of magnetic anomalies and the depth of the magnetic source using Fourier transformation of spatial data (magnetic grid) into wave or frequency domain. Spectral analysis involves estimating the depth to the bottom of the magnetized bodies, which is the transition point for magnetic materials using a log power spectrum. Radially averaged power spectra of magnetic data according to Blanco-Montenegro et al. [47] are expressed as function of wavenumber and are related to the depth to the bottom of the deepest magnetic source:

$$
K_{\max }=\frac{\log z_{b}-\log z_{t}}{z_{b}-z_{t}} .
$$

$z_{t}$ and $z_{b}$ are depths to top and bottom of the magnetic sources, respectively, $K$ is a function of wavenumber, which 


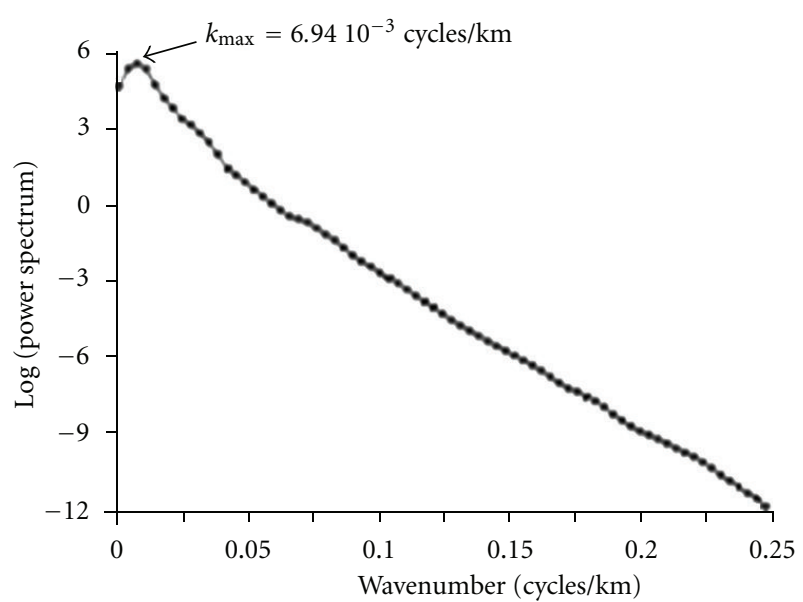

(a)

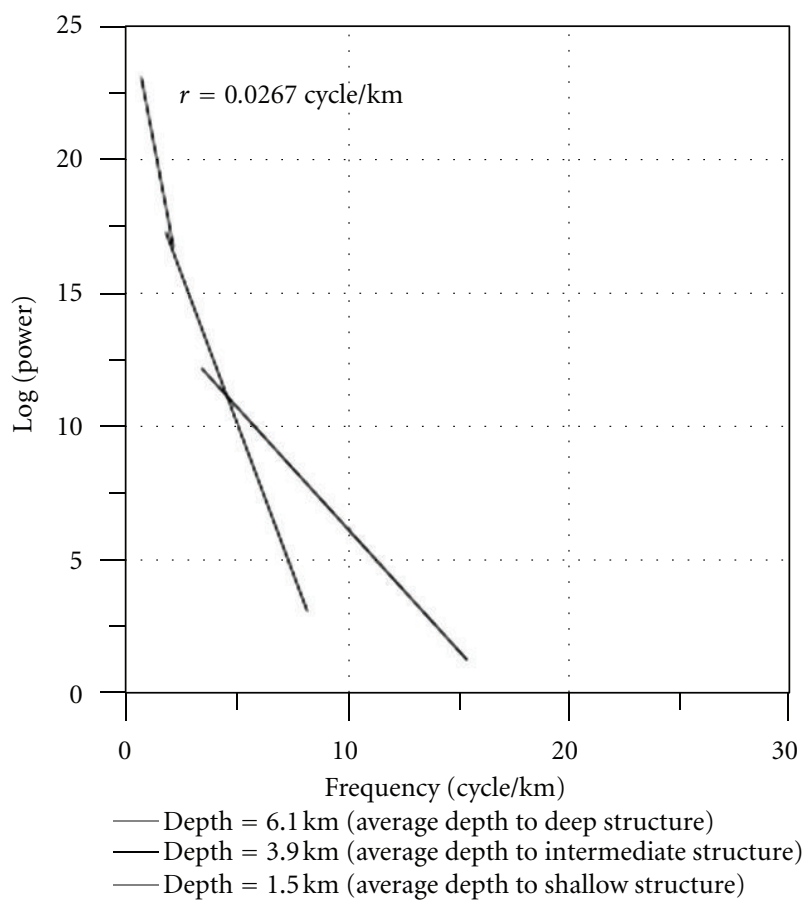

(b)

Figure 13: (a) Radially averaged power spectrum from aeromagnetic data after Blanco-Montenegro et al. [47]. (b) Example of average power spectrum of aeromagnetic anomaly map with depth to the top of magnetic sources $\left(z_{t}\right)$ estimated using least-square method after El-Qady et al. [53].

is expressed in radians per unit distance. The power spectrum according to Spector and Grant [48] can be divided into two parts: (1) the deeper sources with small wavenumbers and decay away rapidly and (2) the shallower sources with high wavenumber, which dominate the short wavelength end of the spectrum (Figure 13(a)). The wavenumber value at maximum peak spectrum (due to deepest anomaly) $K_{\max }$ is usually determined on the generated log power spectrum as shown in Figure 13(a). To obtain the value of the depth to the deepest anomaly, a least-square method is usually adopted to determine the slope at each peak of the log spectrum (Figure 13(b)).
The total magnetic intensity (TMI) grid of the aeromagnetic data in Figure 10, with window size of $(85 \mathrm{~km} \times 75 \mathrm{~km})$ was used for the estimation of the Curie-point depth using spectral analysis technique. This was done using interactive filtering technique in Oasis Montaj MAGMAP extension, which is frequency domain processing of most potential field data. After preparing the magnetic grid (in space domain), it was then transformed to wavenumber (frequency) domain using forward filtering transform (FFT) filters. The Fourier transformation of a space domain function is defined as

$$
\begin{array}{r}
f(x, y)=\frac{1}{4 \pi} \iint_{-\infty}^{\infty} f^{-}(\mu, v) \cdot e^{i(u x+v y)} d \mu d y \\
\text { (space domain), } \\
\bar{f}(\mu, v)=\iint_{-\infty}^{\infty} f(x, y) \cdot e^{-i(\mu x-v y)} d x d y \\
\text { (wavenumber domain), }
\end{array}
$$

where $\mu$ and $v$ are wavenumbers in the $x$ and $y$ directions, respectively, which are measured in radians per metre [49]. The transformation procedures involved application of different filtering functions such as upward and downward continuation. In this study, the upward continuation was applied to remove the effect of shallow sources since the analysis was aimed at estimating depth to deeper magnetic sources. After the filtering application, the inverse filter was applied to the space domain data, which transformed it to wavenumber, or frequency domain from which power spectrum was generated (Figure 14).

The result shows that the depth to top of the deepest magnetic source around Magadi is about $6 \mathrm{~km}$. Estimation of heat source (Curie-point) depth therefore was done by determining the depth to the bottom $\left(Z_{b}\right)$ of the deepest anomaly using (1). The relation requires the depth to the top $\left(Z_{t}\right)$ and the peak wavenumber value $\left(K_{\max }\right.$ in cycle $\left./ \mathrm{km}\right)$ which are derived from the generated power spectrum in Figure 14 as $6 \mathrm{~km}$ and $0.05 \mathrm{cycle} / \mathrm{km}$, respectively. The depth to the bottom of the deepest magnetic material was estimated from (1) to $12.074 \mathrm{~km}$.

\section{Lake Magadi Heat Source and Its Seismotectonic Implications}

The penetration of the magma to the crust produces different geophysical phenomena such as crustal deformation, volcanic activity, and seismicity [50]. In the southern part of the Kenya rift, microseismic activities have been attributed to geothermal processes, as a result of magmatic intrusions into the crust [11]. Magadi earthquake swarm according to Ibsvon Seht et al. $[7,16]$ can be linked to mid-crustal magma body in the centre of the rift and the movement of the magmatic fluids.

To further investigate these findings, the heat source depth (Curie-point depth) generated from the aeromagnetic data was correlated with the seismic hypocenters (depth to the seismic events) and the magnetic sources, revealing 


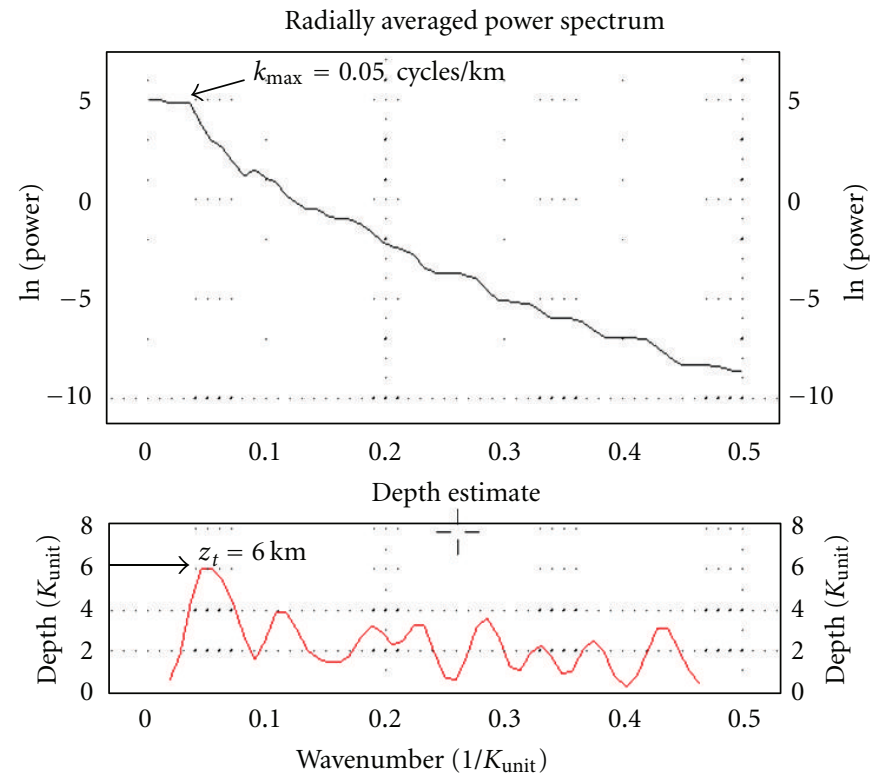

FiguRE 14: Log power spectrum analysis of Lake Magadi generated from aeromagnetic data.

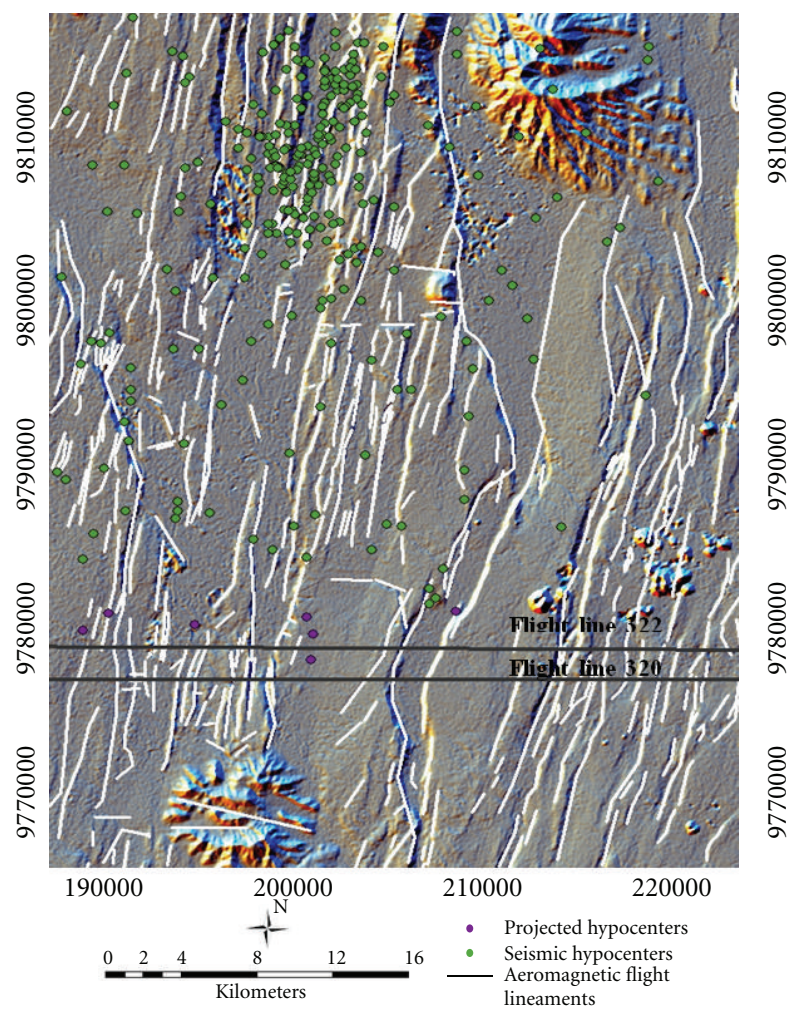

FIgURE 15: Hill-shade AsterDEM image showing the lineaments and seismic hypocenters distributions from Ibs-von Seht et al. [7] around Lake Magadi. The brown dots are the reprojected hypocenters along the aeromagnetic flight lines.

subsurface faulting systems (see Figures 16 and 17). The hypocenters used in this research were the output of the seismic experiments by Ibs-von Seht et al. [7] at Lake Magadi area. Seismic hypocenters which are closed to the aeromagnetic lines 322 and 320 (about $5 \mathrm{~km}$ ) were reprojected to their corresponding latitude along the profile (Figure 15) and are plotted with the sources against depth.

From the scatter plots, it is noted that all the earthquake hypocenters are located between top of the magnetic sources and the bottom (that corresponds to Curie-point depth); 


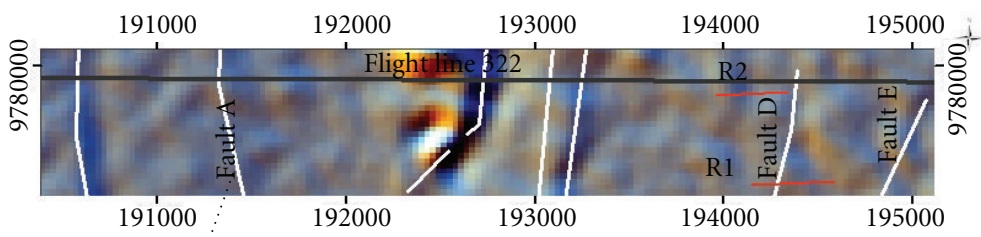

(a)

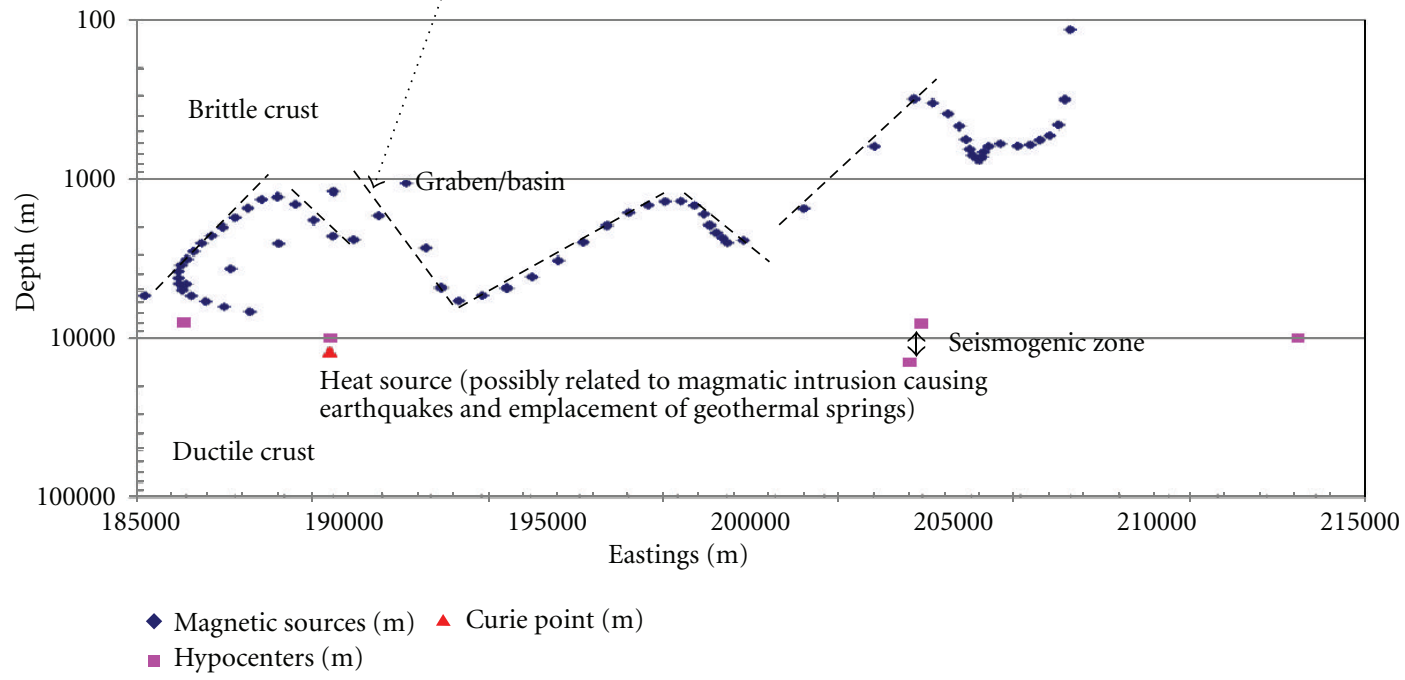

(b)

Figure 16: (a) Hill-shaded aster DEM subset showing the surface lineaments and the extracted aeromagnetic flight line 322 . (b) Scatter Plots showing the subsurface relationship between magnetic sources on flight line 322, the hypocenters and the Curie-point (heat source). The magnetic sources are generated from 2D Euler deconvolution using structural index of 1 (i.e., contacts, faults) with inclinations and declination angles of $-26.3^{\circ}$ and $0.002^{\circ}$, respectively. R1 and R2 are the resistivity profiles 1 and 2, respectively.

this defines the seismogenic layer, the onset of seismicity $[51,52]$. Figures 16 and 17 are consistent with Ibs-von Seht et al.'s [7] crustal model in terms of the heat source depth and active faults locations. The Curie depth that defines elevated temperature corresponds to magmatic intrusion, which drives other processes such as stress accumulation, earthquake generation, and emplacement of hydrothermal solutions. The shallowness of this zone must have resulted in the pronounced deformations, earthquake generation, and surface manifestation of hydrothermal fluids around Lake Magadi, southern Kenya rift. The intrusion of the magma to the mid-crust is attributed to the cause of earthquake swarms; this is because it focuses or releases strain energy in brittle or resistive part of the crust with small magnitude earthquakes [44].

\section{Discussion and Conclusions}

Subsurface investigations in this study reveal the potential presence of fluids (mostly saline hydrothermal) within five major faults in the southern side of Lake Magadi. These faults, which are mostly north-south trending, are the conduits which support the hot springs flow in the lake margin and the trona deposits on the lake floor. Within the faults are the general funnel-shaped structures, with very low resistivity $(<1 \mathrm{ohm}-\mathrm{m})$ in most of the resistivity models, indicating that Magadi area is host to mostly high saline ground water and hot springs reservoir. It was observed that the resistivity distribution increases from near the surface to the deep subsurface. These variations could be attributed to the saline concentration differences. The tectonic activity in the Lake Magadi upper crust contributes to the upward flow of hydrothermal fluids from the hot geothermal reservoir to the surface.

Both resistivity and magnetic results show that the existence of the investigated structures in the south of Lake Magadi plays an important role in creating a flow path through which the hydrothermal fluids (hot or cold) are transported to the surface. The change in the direction of the fluid path could result from tectonic activities; it follows the subsurface faults splay (minor fault at the extreme of the major fault) to the surface. This implies that the flow of the fluids has been highly supported by the existence of the $\mathrm{N}$ $S$ fault structures in the study area; this is obvious with the existence of springs in the north direction toward the lake, within the five structures bounding the graben. These low resistivity zones could be because of continuous deformation due to an extensive network of the fluid fractures, which maintain electrical connection.

The heat source in Lake Magadi is inferred to be a magmatic body, emplaced at an approximate depth of 


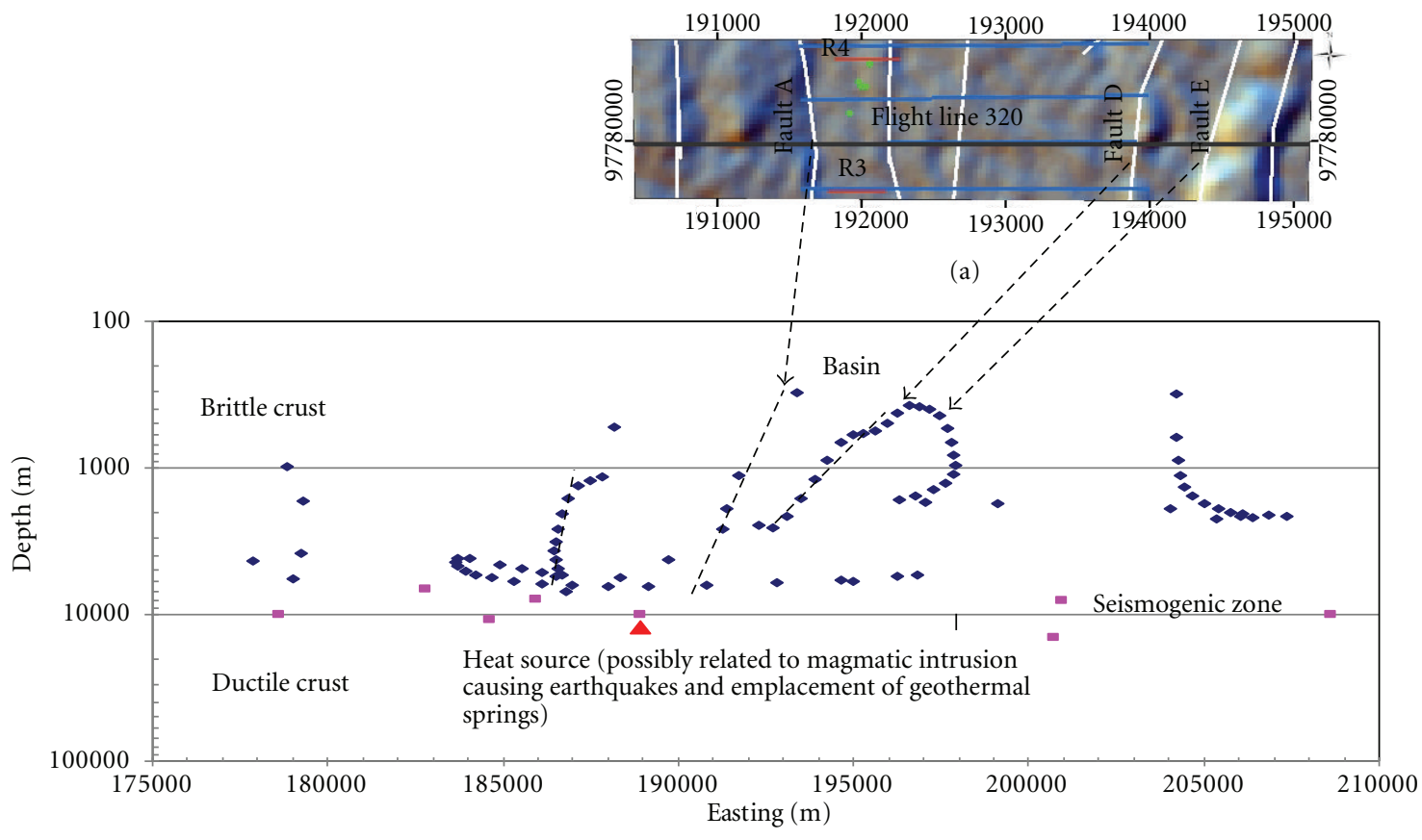

- Magnetic source $\operatorname{depth}(\mathrm{m})$ ॥ Curie point $(\mathrm{m})$

- Hypocenters $(\mathrm{m})$

(b)

FIgURE 17: (a) Hill-shaded ASTER DEM subset showing the surface lineaments and the extracted aeromagnetic flight line 320. (b) Scatter plots showing the subsurface relationship between magnetic sources on flight line 320, the hypocenters, and the Curie-point (heat source). The magnetic sources are generated from 2D Euler deconvolution using structural index of 1 (i.e., contacts, faults) and inclinations and angles of $-26.3^{\circ}$ and $0.002^{\circ}$, respectively. R3 and R4 are the resistivity profiles 3 and 4 , respectively. The blue horizontal lines are the ground magnetic profiles location.

$12.1 \mathrm{~km}$ (Magadi mid-crust). The Curie depth that defines elevated temperature corresponds to magmatic intrusion, which drives other processes such as stress accumulation, earthquake generation, and emplacement of geothermal solutions. The shallowness of this zone possibly resulted in pronounced deformations, earthquake generation, and surface manifestation of hydrothermal fluids around Lake Magadi, southern Kenya rift.

\section{Acknowledgments}

The authors appreciation goes to the University of Twente, ITC, Enschede, The Netherlands, and Nuffic for funding the study. We are most grateful to Dr. Ibs-von Seht from Hannover, Germany, for providing them seismogram for Magadi area. They acknowledge the supports rendered by the Department of Geology, University of Nairobi, for allowing the use of its resistivity equipment. They also thank Dr. Sally Barrit of the University of Twente, ITC, Enschede, for the provision of aeromagnetic data.

\section{References}

[1] G. Blewitt, M. Coolbaugh, W. Holt, C. Kreemer, J. L. Davis, and R. A. Bennett, "Targeting of potential geothermal resources in the great basin from regional relationships between geodetic strain and geological structures," in Proceedings of the Annual Meeting Geothermal Resources Council, pp. 523-525, September 2002.

[2] M. Babiker and A. Gudmundsson, "The effects of dykes and faults on groundwater flow in an arid land: the Red Sea Hills, Sudan," Journal of Hydrology, vol. 297, no. 1-4, pp. 256-273, 2004.

[3] N. Tüfekçi, M. Lütfi Süzen, and N. Güleç, "GIS based geothermal potential assessment: a case study from Western Anatolia, Turkey," Energy, vol. 35, no. 1, pp. 246-261, 2010.

[4] J. Wheildon, P. Morgan, K. H. Williamson, T. R. Evans, and C. A. Swanberg, "Heat flow in the Kenya rift zone," Tectonophysics, vol. 236, no. 1-4, pp. 131-149, 1994.

[5] H. D. Mary and F. Mario, What Is Geothermal Energy? Istituto di Geoscienze e Georisorse, Pisa, Italy, 2004.

[6] Y. Noorollahi, R. Itoi, H. Fujii, and T. Tanaka, "GIS model for geothermal resource exploration in Akita and Iwate prefectures, northern Japan," Computers and Geosciences, vol. 33, no. 8, pp. 1008-1021, 2007.

[7] M. Ibs-von Seht, S. Blumenstein, R. Wagner, D. Hollnack, and J. Wohlenberg, "Seismicity, seismotectonics and crustal structure of the Southern Kenya Rift-new data from the Lake Magadi area," Geophysical Journal International, vol. 146, no. 2, pp. 439-453, 2001.

[8] Z. N. Kuria, T. Woldai, F. D. V. D. Meer, and J. O. Barongo, "Active fault segments as potential earthquake sources: inferences from integrated geophysical mapping of the Magadi 
fault system, southern Kenya Rift," Journal of African Earth Sciences, vol. 57, no. 4, pp. 345-359, 2010.

[9] P. Molnar and Y. P. Aggarwal, "A microearthquake survey in Kenya," Bulletin of the Seismological Society of America, vol. 61, no. 1, pp. 195-201, 1971.

[10] B. F. Jones, H. P. Eugster, and S. L. Rettig, "Hydrochemistry of the Lake Magadi basin, Kenya," Geochimica et Cosmochimica Acta, vol. 41, no. 1, pp. 53-72, 1977.

[11] P. K. H. Maguire and R. E. Long, "The structure on the western flank of the gregory Rift (Kenya). Part I. the crust," Geophysical Journal of the Royal Astronomical Society, vol. 44, pp. 661-675, 1976.

[12] S. M. Simiyu and G. R. Keller, "Seismic monitoring of the Olkaria Geothermal area, Kenya Rift valley," Journal of Volcanology and Geothermal Research, vol. 95, no. 1-4, pp. 197$208,2000$.

[13] F. Mwaura, "A spatio-chemical survey of hydrogeothermal springs in Lake Elementaita, Kenya," International Journal of Salt Lake Research, vol. 8, no. 2, pp. 127-138, 1999.

[14] N. Atmaoui and D. Hollnack, "Neotectonics and extension direction of the Southern Kenya Rift, Lake Magadi area," Tectonophysics, vol. 364, no. 1-2, pp. 71-83, 2003.

[15] W. Bosworth, M. R. Strecker, and P. M. Blisniuk, "Integration of East African paleostress and present-day stress data: implications for continental stress field dynamics," Journal of Geophysical Research, vol. 97, no. 8, pp. 11-865, 1992.

[16] M. Ibs-von Seht, T. Plenefisch, and K. Klinge, "Earthquake swarms in continental rifts-a comparison of selected cases in America, Africa and Europe," Tectonophysics, vol. 452, no. 1-4, pp. 66-77, 2008.

[17] S. M. Simiyu and G. R. Keller, "Upper crustal structure in the vicinity of Lake Magadi in the Kenya Rift Valley region," Journal of African Earth Sciences, vol. 27, no. 3-4, pp. 359-371, 1998.

[18] H. P. Eugster, "Chemistry and origin of brines of Lake Magadi, Kenya," in Mineral Sopciety American Spec, vol. 30, pp. 215235,1970

[19] J. Chorowicz, “The East African rift system," Journal of African Earth Sciences, vol. 43, no. 1-3, pp. 379-410, 2005.

[20] B. H. Baker, L. A. J. Williams, J. A. Miller, and F. J. Fitch, "Sequence and geochronology of the Kenya rift volcanics," Tectonophysics, vol. 11, no. 3, pp. 191-215, 1971.

[21] L. W. Braile, B. Wang, C. R. Daudt, G. R. Keller, and J. P. Patel, "Modeling the 2-D seismic velocity structure across the Kenya rift," Tectonophysics, vol. 236, no. 1-4, pp. 251-269, 1994.

[22] P. K. H. Maguire, C. J. Swain, R. Masotti, and M. A. Khan, "A crustal and uppermost mantle cross-sectional model of the Kenya Rift derived from seismic and gravity data," Tectonophysics, vol. 236, no. 1-4, pp. 217-249, 1994.

[23] J. Mechie, G. R. Keller, C. Prodehl et al., "Crustal structure beneath the Kenya Rift from axial profile data," Tectonophysics, vol. 236, no. 1-4, pp. 179-200, 1994.

[24] C. Prodehl, J. R. R. Ritter, J. Mechie et al., "The KRISP 94 lithospheric investigation of southern Kenya-the experiments and their main results," Tectonophysics, vol. 278, no. 1-4, pp. 121147, 1997.

[25] B. H. Baker, Outline of the Petrology of the Kenya Rift Alkaline Province, vol. 30, Geological Society, Special Publications, London, UK, 1987.

[26] G. R. Keller, C. Prodehl, J. Mechie et al., "The East African rift system in the light of KRISP 90," Tectonophysics, vol. 236, no. 1-4, pp. 465-483, 1994.

[27] G. R. Keller, J. Mechie, L. W. Braile, W. D. Mooney, and C. Prodehl, "Seismic structure of the uppermost mantle beneath the Kenya rift," Tectonophysics, vol. 236, no. 1-4, pp. 201-216, 1994.

[28] J. Mechie, G. R. Keller, C. Prodehl, M. A. Khan, and S. J. Gaciri, "A model for the structure, composition and evolution of the Kenya rift," Tectonophysics, vol. 278, no. 1-4, pp. 95-119, 1997.

[29] C. Le Turdu, J. J. Tiercelin, J. P. Richert et al., "Influence of preexisting oblique discontinuities on the geometry and evolution of extensional fault patterns, Evidence from the Kenya Rift using Spot Imagery," in Geoscience of Rift Systems-Evolution of East Africa, pp. 173-191, AAPG Studies in Geology, 1999.

[30] M. Smith and P. Mosley, "Crustal heterogeneity and basement influence on the development of the Kenya Rift, East Africa," Tectonics, vol. 12, no. 2, pp. 591-606, 1993.

[31] B. H. Baker, Geology of the Magadi Area, Geological Survey of Kenya, Nairobi, Kenya, 1958.

[32] A. K. Thurmond, M. Abdel-Salam, Z. Yin, A. Hassanipak, and A. M. Ghazi, "Structural Analysis of the Khoy Ophiolite, NW Iran from ASTER Imagery," in American Geophysical Union, A. G. Union, Ed., Spring, 2002.

[33] X. Yang, D. Liu, and J. Zhang, "Ore-search information using aster data in bashibulake uranium deposit area in xinjiang," The International Archives of the Photogrammetry, Remote Sensing and Spatial Information Sciences, vol. 36, Article ID B6b, 2008.

[34] V. Teichrieb and J. Kelner, "Enhancement of radar based DEMs using 3D techniques," in Proceedings of the IEEE International Geoscience and Remote Sensing Symposium (IGARSS '07), pp. 4902-4905, Barcelona, Spain, June 2007.

[35] H. P. Eugster, "Lake Magadi, Kenya: a model for rift valley hydrochemistry and sedimentation?" Geological Society, London, Special Publications, vol. 25, pp. 177-189, 1986.

[36] S. R. Wilson, M. Ingham, and J. A. McConchie, "The applicability of earth resistivity methods for saline interface definition," Journal of Hydrology, vol. 316, no. 1-4, pp. 301-312, 2006.

[37] H. M. Bibby, G. F. Risk, T. Grant Caldwell, and W. Heise, "Investigations of deep resistivity structures at the Wairakei geothermal field," Geothermics, vol. 38, no. 1, pp. 98-107, 2009.

[38] T. M. Hunt, C. J. Bromley, G. F. Risk, S. Sherburn, and S. Soengkono, "Geophysical investigations of the Wairakei Field," Geothermics, vol. 38, no. 1, pp. 85-97, 2009.

[39] G. R. J. Cooper, "Euler deconvolution applied to potential field gradients," Exploration Geophysics, vol. 35, no. 3, pp. 165-170, 2004.

[40] N. O. Mariita and G. R. Keller, "An integrated geophysical study of the northern Kenya rift," Journal of African Earth Sciences, vol. 48, no. 2-3, pp. 80-94, 2007.

[41] A. A. Adepelumi, B. D. Ako, T. R. Ajayi, A. O. Olorunfemi, M. O. Awoyemi, and D. E. Falebita, "Integrated geophysical mapping of the Ifewara transcurrent fault system, Nigeria," Journal of African Earth Sciences, vol. 52, no. 4-5, pp. 161-166, 2008.

[42] M. F. Mushayandebvu, P. Van Driel, A. B. Reid, and J. D. Fairhead, "Magnetic source parameters of two-dimensional structures using extended Euler deconvolution," Geophysics, vol. 66, no. 3, pp. 814-823, 2001.

[43] A. Stampolidis and G. N. Tsokas, "Curie point depths of Macedonia and Thrace, N. Greece," Pure and Applied Geophysics, vol. 159, no. 11-12, pp. 2659-2671, 2002.

[44] A. Gürer and M. Bayrak, "Relation between electrical resistivity and earthquake generation in the crust of West Anatolia, Turkey," Tectonophysics, vol. 445, no. 1-2, pp. 49-65, 2007. 
[45] M. G. El Dawi, L. Tianyou, S. Hui, and L. Dapeng, "Depth estimation of 2-D magnetic anomalous sources by using Euler deconvolution method," American Journal of Applied Sciences, vol. 1, no. 3, pp. 209-214, 2004.

[46] J. M. Espinosa-Cardeña and J. O. Campos-Enriquez, "Curie point depth from spectral analysis of aeromagnetic data from Cerro Prieto geothermal area, Baja California, México," Journal of Volcanology and Geothermal Research, vol. 176, no. 4, pp. 601-609, 2008.

[47] I. Blanco-Montenegro, J. M. Torta, A. García, and V. Arana, "Analysis and modelling of the aeromagnetic anomalies of Gran Canaria (Canary Islands)," Earth and Planetary Science Letters, vol. 206, no. 3-4, pp. 601-616, 2003.

[48] A. Spector and F. S. Grant, "Statistical models for interpreting aeromagnetic data," Geophysics, vol. 35, pp. 293-302, 1970.

[49] Geosoft, Montaj MAGMAP Filtering: 2D Frequency Domain Processing of Potential Field Data, Geosoft Incorporated, Toronto, Canada, 2005.

[50] M. Mishina, "Distribution of crustal fluids in Northeast Japan as inferred from resistivity surveys," Gondwana Research, vol. 16, no. 3-4, pp. 563-571, 2009.

[51] A. Björnsson, "Temperature of the Icelandic crust: inferred from electrical conductivity, temperature surface gradient, and maximum depth of earthquakes," Tectonophysics, vol. 447, no. 1-4, pp. 136-141, 2008.

[52] K. Ito, "Seismogenic layer, reflective lower crust, surface heat flow and large inland earthquakes," Tectonophysics, vol. 306, no. 3-4, pp. 423-433, 1999.

[53] G. El-Qady, A. Salem, E. Aboud, A. Khalil, and K. Ushijima, Geothermal Reconnaissance Study for Sinai Peninsula, Egypt, World Geothermal Congress, Antalya, Turkey, 2005. 

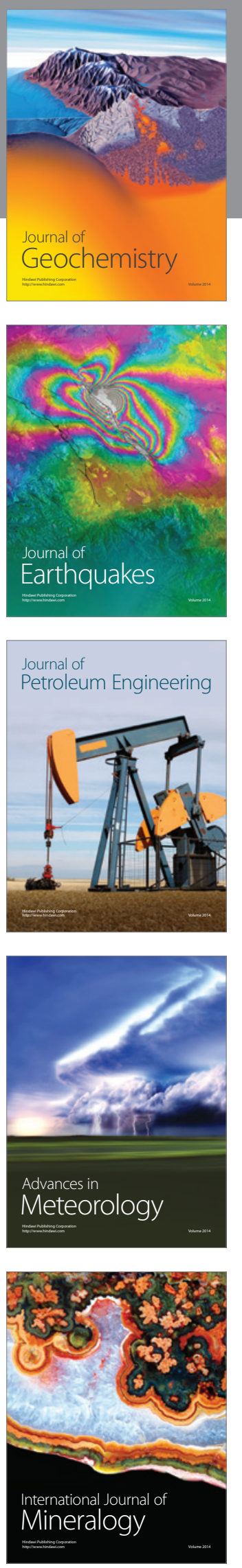
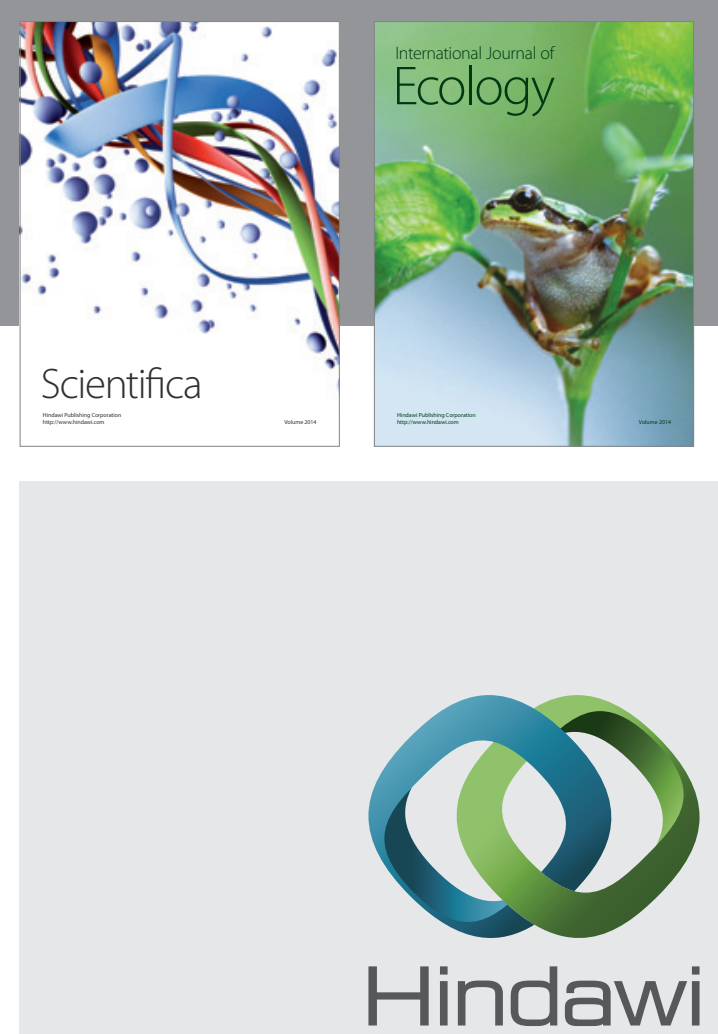

Submit your manuscripts at http://www.hindawi.com
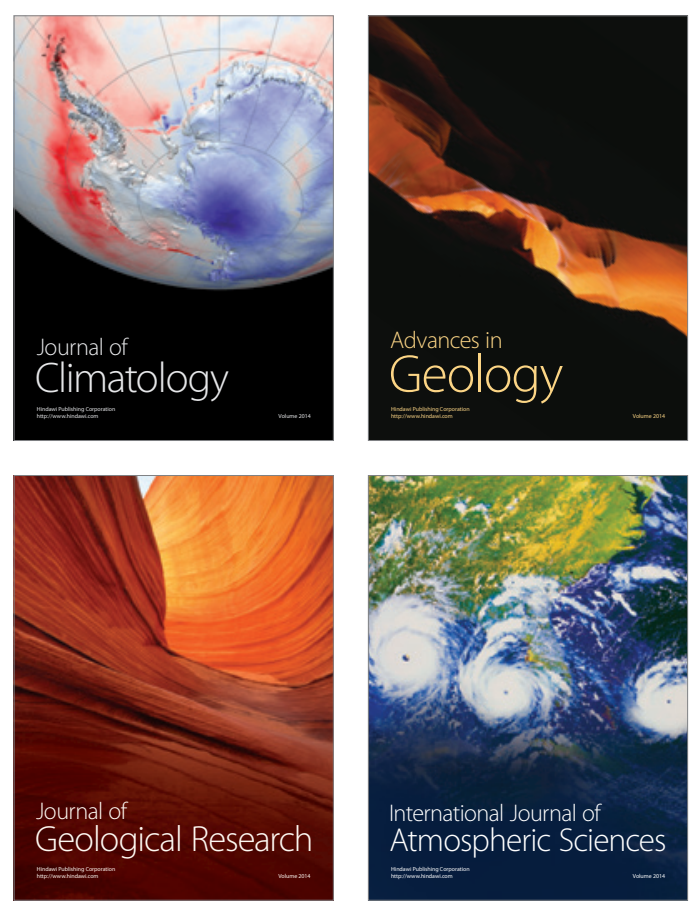
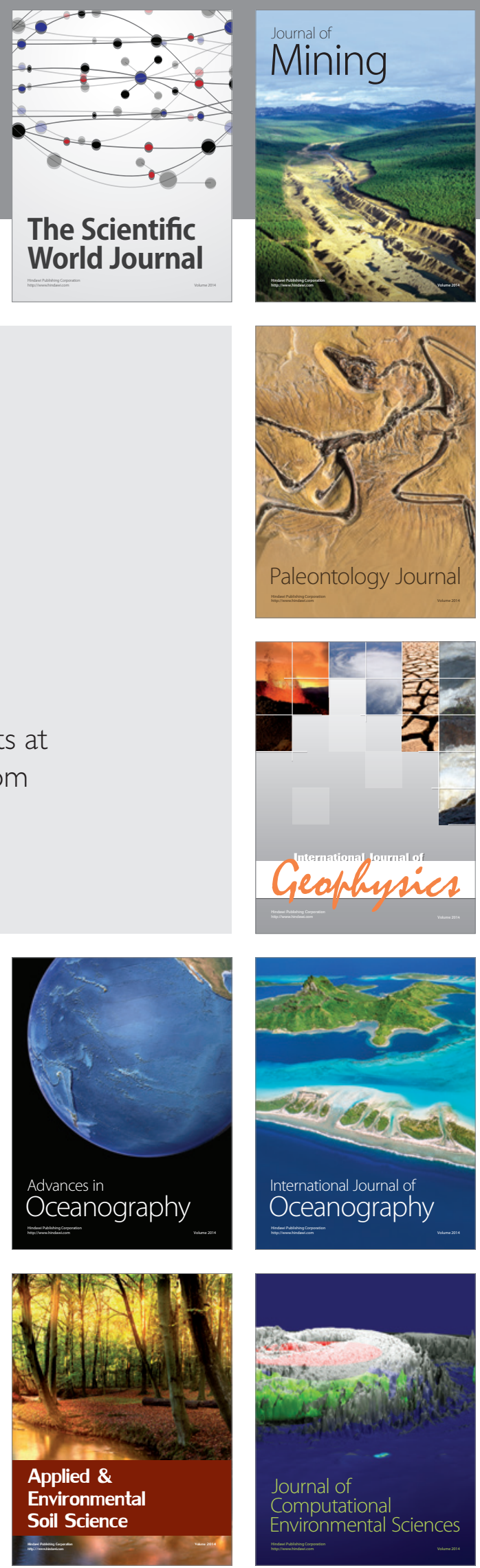